\title{
Critical Literacy of Kreo Cave as Solution to Improve Religious Character Learning
}

\author{
Evi Chamalah ${ }^{1}$, Leli Nisfi Setiana ${ }^{2}$, Reni Nuryyati ${ }^{3}$ \\ Universitas Islam Sultan Agung ${ }^{1 \& 2}$, Universitas Gadjah Mada ${ }^{3}$ \\ \{chamalah@unissula.ac.id¹, lelinisfi@unissula.ac.id²,nuryyati.reni@yahoo.com³\}
}

\begin{abstract}
Critical literacy skills are needed in learning at schools and colleges. One of ways to increase this ability is through literature. One of literary work that is potential to increase critical literacy is a legend. The legend of Kreo cave is one of the legends of the city named Semarang which has an important role in the spread of Islam in Central Java. This research is a qualitative descriptive study using a literary semiotics approach. This study uses three techniques, namely photo shoot techniques, observation techniques, and recording techniques. The results of this study are (1) a description of the symbolic meaning in the legend of Kreo cave, (2) a description of the critical literacy of the legend of Kreo cave, (3) a description of the increase in learning religious characters through critical literacy of the legend of Kreo cave.
\end{abstract}

Keywords: critical literacy, legend, Kreo cave, learning, religious character

\section{Introduction}

Education is the most important factor in determining the quality of every human being. The Constitution in 2003 concerning the National Education System state that there must be real efforts from government to carry out the learning process so that students may actively develop their potential to acquire various knowledge such as religion, self-control, personal character, intelligence, morals, and skills needed by each individual [30]. The success of education in a country cannot be separated from the literacy culture of its society. Literacy is the ability to practice social situations, historical situations, and cultural situations as part of creating and interpreting the meaning of a text [12]. Currently, various countries around the world are discussing the effect of literacy on improving learning for students. In simple terms, literacy is a reading and writing ability that a person has [31]. However, currently, literacy is expanding more widely. A person can be said to be literate if he has understood a concept of information based on his understanding from a reading. Creating a literate society requires a long process and conducive means. This process, of course, starts from the family environment, continues and is developed at school, in the social environment, and develops into the work environment.

Data from the 2011 PIRLS shows that the results of the reading literacy test for Indonesians are ranked $45^{\text {th }}$ out of 48 countries with a score of 428 out of an average score of 500 , while the reading literacy test in PISA 2009 shows Indonesian students are ranked 57 $7^{\text {th }}$ with a score 396 (OECD average score 493), while PISA 2012 shows that Indonesian students 
are ranked 64th with a score of 396 (OECD average score 496) [16]. A total of 65 countries participated in PISA 2009 and 2012. PIRLS and PISA data, especially in reading comprehension skills, show that the competence of Indonesian students is low [10]. It shows that the level of literacy of Indonesian society is still in the low category. In addition, based on data from the Central Bureau of Statistics in 2006, it shows that people in Indonesia prefer to watch television and listen to the radio compared to reading [26]. Based on the results of the study, Indonesian society, especially students in schools, must make reading and writing literacy a part of life's necessities.

From the current perspective, the paradigm of literacy learning embraces critical literacy theory. This relates to text-based learning to better understand a new concept. Critical literacy is the ability to read a text actively and reflectively to gain a new understanding of power, inequality, inequality, and human relations [29]. Another opinion reveals that critical literacy is a combination of a person's skills in thinking critically about a problem regarding social justice, politics, language, and the power contained in certain texts [9]. Based on the opinion of some experts, critical literacy is closely related to the patterns of learning in schools and the reading provided by educators. Education from critical literacy provides opportunities for students to explore and educate about character values.

Inculcating character values in high school students and university students is necessary because there're still some poor characters in the community. It can be seen from the behavior of cheating, truancy, etc. carried out by students during learning activities [2]. Rahardjo revealed that character education is an educational process that connects the moral and social dimensions in real life [20]. More specifically, Prasetyo revealed that character education is a system of cultivating character values such as the components of knowledge, awareness, and actions to carry out these character values to become Islamic humans [19]. Based on the understanding of the two experts, character education is a system of planting moral values that are quite important for future life. Omeri revealed that character education is very important in the school environment and the social environment [18]. In line with the opinion above, Oktariana revealed that character education in students in schools could be in the form of awareness and willingness to carry out proper character values [17]. Furthermore, character education can make a person develop the potential of a conscience, carry out praiseworthy habits and behavior, increase independence, instill leadership, and develop social skills in life. It shows that character education is an important factor that must be given to every human being.

There are four types of character that must be instilled in the educational process. Yahya revealed that the four types of character that must be applied are religious character education, cultural value character education, environmental character education, and self-potential character education [33]. The four types of characters are described more broadly by the Ministry of National Education into 18 characters, namely religious, honest, tolerant, disciplined, hard work, creative, independent, democratic, curiosity, national spirit, love for the country, respect for achievement, friendly or communicative, love. peaceful, fond of reading, caring for the environment, caring socially, and responsibility [11]. The main character applied in the Ministry of Education since 2010 is a religious character. The religious character instilled in character education is one way of realizing the first principle of Pancasila which contains the meaning of morality and spirituality as an important role in the sustainability of a country. Religious character is the attitude and behavior that is obedient or obedient in implementing religious teachings so that they are tolerant and live in harmony with other religions [11]. Efforts to improve religious character are certainly not easy and go 
through a long process. In the formation of religious character, it is necessary to have an action or effort made by someone such as providing religious character education.

Religious character education is a way to shape a person's personality according to the teachings of the religion he embraces. Religious character education that is implemented in the world of education can be integrated with various reading materials such as a legend. Danandjaja explained that the legend is a folk tale that is considered to have happened by people in an area [5]. Furthermore, Luxemburg revealed that a legend is a literary work formed based on social phenomena related to the character values and customs of society within a certain period [13]. Based on this opinion, legends can be one way to increase character values in students and students. One of the legends in Indonesia that is well known to the Javanese people, especially Central Java, is The Legend of the Kreo cave. The legend of the Kreo cave is one of the folk tales from Semarang, precisely in Mijen District, Semarang, Central Java. This legend tells a story about the journey of a Wali Songo who will build a mosque in the Central Java area. The use of the Legenda Kreo cave is expected to increase the values of a religious character in students and students.

Several experts have researched literacy and critical literacy. The first research was conducted by Balfas [3], Geske [6], Syahrani [27], Ariyanthi, et al [1], Musfiroh dan Beniati [15], Ismayani [8], Syahrul [28], Harsiati [7], Rahman and Cutri [21], Muthoharoh [14]. This research is a continuation of previous research related to critical literacy. The difference is this research is about the critical literacy of Legend of Kreo cave. Based on this background, the formulation of the research problems are (1) what is the symbolic meaning in the Legend of Kreo cave? (2) How is the critical literacy of Legend of Kreo cave? (3) How to improve religious learning through the critical literacy of the Legend of Kreo cave? The objectives of this study are (1) to describe the symbolic meaning of the Legend of Kreo cave (2) to describe the critical literacy of the Legend of the Kreo cave and (3) to describe the improvement of religious learning through the critical literacy of the Legend of Kreo cave.

\section{Methods}

This research uses descriptive qualitative research methods. Sugiyono revealed that qualitative research is a study that uses the philosophical basis of postpositivism to identify natural objects [23]. In line with this, Sukmadinata revealed that qualitative research is used by researchers to understand social phenomena that exist in society [24]. Based on the two opinions above, it can be seen that this study is a study to determine social phenomena that occur in society with researchers as the key instrument. The data from this research are in the form of words, phrases, clauses, and sentences contained in the Legend of the Kreo cave. Sources of data in this study consisted of two sources, namely primary and secondary sources. The primary data source of this study is the legendary text of the Kreo cave in Semarang, Central Java. Secondary data sources in this study are supporting data from various relevant sources such as the internet, newspapers, journals, and so on which are related to the Legend of the Kreo cave.

Data collection techniques in oral literature include (1) recording techniques, (2) photo shoot techniques, (3) observation, (4) recording, (5) interviews, (6) questionnaires [22]. Due to the limitations of the research, from the six techniques, this study used three techniques, namely shooting techniques, observation techniques, and recording techniques. The photo shoot technique is used to document everything related to the research, namely regarding the research location and the conditions of the research location. Researchers came to the Kreo 
cave to document the location and conditions of the Kreo cave location. The second technique is the observation technique. In this technique, the researcher is present directly in the Kreo cave to observe and study the research location, to see the existence of the research object. The third technique is the recording technique. In this technique, the researcher notes things in the Kreo cave.

The data analysis technique in this research was carried out through several stages as expressed by Sulistyorini and Eggy, namely (1) data collection, (2) data classification, (3) data interpretation, (4) classification, (5) data commentation, and (6) data inference [25In data collection techniques, researchers collect data that contain symbolic meaning and religious value. In data classifying techniques, the data obtained is then classified. In data interpretation techniques, data that have been grouped are interpreted by providing an interpretation of the meaning according to the research problem. In the data classification technique, existing data are grouped with activities in the form of reading the text of the Legend of Kreo cave intensively to obtain a complete picture, linking the data that has been found with the criteria that have been made according to the problem formulation and entering the data into categories. In the data interpretation technique, it is carried out by analyzing the classification of the data that has been collected in accordance with the problem under study. The final technique is data inference, which is data that has been interpreted and then described in the form of exposure to the results of the analysis. The approach in this study is to use a semiotic approach regarding codes, symbols of symbols, meanings, and signs found in the Kreo cave location.

\section{Result and Discussion}

The legend of Kreo cave is one of the legends that developed in the community of Semarang and its surroundings. The legend of the Kreo cave tells of Sunan Kalijaga's journey while looking for wood to build a place of worship. Currently, the legend of the Kreo cave is still believed by the people around the Kreo cave as a legend that happened in the past. In this section, the results of research on the symbolic meaning contained in the Legend of the Kreo cave will be presented, the critical literacy of the Legend of the Kreo cave, and the improvement of learning religious characters through the critical literacy of the Legend of the Kreo cave. The following is a further explanation of the three research results.

\subsection{Symbolic Meanings in the Legend of Kreo Cave}

In the life of the Javanese people, several cultural products contain symbolic values and meanings. This is what makes Javanese people always reflect the symbolic meaning in every story or legend in an area. In the Legend of the Kreo cave, for example, there are several symbolic meanings concerning the characters in the story, the storyline, or the background of the story. In semiotic or sign theory, literary works are placed as a sign that is formed based on other signs that are present. This sign plays an important role in meaning in accordance with the conventions of a literary work. The symbolic meaning in this discussion is a description of something inherent in literary works and has its own meaning. In connection with the legend of the Kreo cave, there are various symbolic meanings that appear based on the story. The following describes three symbolic meanings that appear in the Legend of the Kreo cave story. 


\section{a) The Legend of Kreo Cave as A Symbol of Obedience to God}

The legend of Kreo cave cannot be separated from the existence of Wali Songo in Java. The collapse of several Hindu Buddhist kingdoms in Indonesia was one of the moments for the saints to spread Islam throughout Java. The legend of the Kreo cave begins when the guardians carry out a mission to build a mosque in the Glagah Wangi area. The mission of the saints is a symbol that the saints are figures who are obedient to God. Their obedience is proven by their willingness and belief to build houses of worship as an effort to spread Islam in Java. After deliberation, the nine guardians, often known as Wali Songo, looked for teak wood to support the mosque they were going to build. Some of the guardians looking for wood are Sunan Ampel, Sunan Bonang, Sunan Gunung Jati, and Sunan Kalijaga. Sunan Kalijaga carried out the task of looking for wood in the southern area along with several of his followers. In the Legend, Sunan Kalijaga always encountered various problems when carrying wood from the southern area to the Glagah Wangi area. However, Sunan Kalijaga never gave up. Sunan Kalijaga always said a prayer for instructions to bring wood to Glagah Wangi.

The success of Sunan Kalijaga in bringing home the wood he had found by praying to God shows that obedience to God will bring success. Sunan Kalijaga's obedience to God which is symbolized by praying continuously when having difficulty shows that in the Legend of the Kreo cave there is a symbol of obedience to God. This symbol is interpreted through the actions of a character who continues to say a prayer every time he experiences difficulties in completing his mission to find wood as a pillar for the mosque.

\section{b) The legend of the Kreo cave as a Symbol of the Success of the Sunan Kalijaga Command}

It is told in a legend, Sunan Kalijaga met four monkeys, namely the red monkey, the white monkey, the yellow monkey, and the black monkey. The monkeys want to help Sunan Kalijaga to bring wood to the Glagah Wangi area. However, Sunan Kalijaga did not allow the four monkeys to help him. The four monkeys were asked by Sunan Kalijaga to guard the cave and river that had been used by Sunan Kalijaga to pray to God. The four monkeys finally guarded the cave and Sunan Kalijaga continued his journey to the Glagah Wangi area. The existence of monkeys in the Kreo cave is a symbol that Sunan Kalijaga has succeeded in commanding the four monkeys to guard an area in the Central Java region. Until now, an increasing number of monkeys in the Kreo cave are believed and believed to be descended from the four monkeys who came when Sunan Kalijaga prayed to God. This legend interprets that a guardian like Sunan Kalijaga can command an animal to guard a place. This command has never been violated or ignored by the beast to date.

\section{c) The legend of the Kreo cave as a symbol of the grounding of Islam in Java}

In the Legend of the Kreo cave, it appears that Islam and Islamic culture have come and entered Java. In the legend, Walisongo as one of the leading figures in the spread of Islam has the vision to build a mosque in the Demak area. With this vision, it can be interpreted that the Islamic religion that entered Java began to be disseminated through the construction of houses of worship. Efforts to ground Islam and Islamic culture in Java are certainly not easy. Among the people, Hindu Buddhist culture still influences the daily life of Javanese people. Walisongo's success in grounding Islam in Java could not be separated from the wise actions of the guardians when solving problems. With the figure of Sunan Kalijaga, Islam is 
interpreted as good religion. This is evidenced by the problem solving is always done by praying and asking God for help.

\subsection{Critical Literacy of Kreo cave Legend}

Everyday human life, especially school-age and students, is difficult to separate from the flow of information. Meanwhile, the culture of critical literacy is a skill that children who always access information must possess and improve. Literacy activities cannot be separated from reading and writing. This literacy activity can be done by reading and understanding various legends that develop in society. One of them is the legend of Kreo cave. This legend tells of a monkey's obedience to the command of a guardian named Sunan Kalijaga. The legend of the Kreo cave can be used as a critical literacy material for learning in schools and colleges. Legend is a literary work that has a moral message in the story. In literacy activities, Wulandari revealed that students must understand several aspects such as reading the text well, understanding the ideas in the text, and being able to write something based on the reading that has been read [32].

Based on this theory, the critical literacy of Legend of Kreo cave refers to critical reading activities according to the theory expressed by Chamalah through seven stages $/ 7 \mathrm{M}$, which are as follows [4]. The first stage, motivating students to read The Legend of the Kreo cave. The second stage, instructs students to read the Legend text of the Kreo cave. In the third stage, students understand the text of the Legend of Kreo cave through several questions. The fourth stage is to criticize. The critical activity was carried out by answering reorganization questions, inference questions, and evaluation questions related to The Legend of the Kreo cave. The fifth stage is rewriting. At this stage, the students rewrote the Legend of the Kreo cave that had been read in summary form. The sixth stage, namely creating. At this stage, students produce another form of the Legend of the Kreo cave, namely in the form of creative writing of short stories, poetry, novels, or drama texts. The seventh stage is publishing. At this stage, students publish their writings on social media Facebook, Instagram, WhatsApp, or other social media.

Reading the legend with critical literacy can provide knowledge about the legend to learners and at the same time provide an overview of the values and characters implied in the story. Indirectly, character learning also takes place when the critical literacy of the Legend of the Kreo cave is conducted. The focus in learning to read the Legend of the Kreo cave with critical literacy is to read the text of Legend of the Kreo cave in-depth, to find social practices and character values in the text of Legend of the Kreo cave, and to conduct a critical study by finding out the dominant message in the text of Legend of the Kreo cave. The message contained in the Legend of the Kreo cave is a symbol of obedience to God as a form of religious character possessed by the main character, Sunan Kalijaga. This religious character can be seen in the actions of a character who always prays and asks God for protection when he gets into trouble.

\subsection{Improved Learning of Religious Characters through the Critical Literacy of the of Kreo Cave Legend}

Learning a religious character is one solution to forming a better person. Learning religious character can be done with critical literacy which is applied to students. One of the readings that can be used for critical literacy as an improvement in learning religious characters is Legenda Kreo cave. This legend is part of a story that lives in the community about an event 
in the past. The legend of the Kreo cave tells of a guardian looking for wood to build a mosque in the Glagah Wangi area. The legend of the Kreo cave is one of the legends that is suitable for critical literacy in improving the learning of religious characters. This is of course because the legend of the Kreo cave contains several character values that contain the meaning of morality and spirituality. The story about Sunan Kalijaga in the legend interprets someone who has a religious character. The way the Sunan Kalijaga figure resolves problems by praying to God shows his obedience to God.

Based on this description, the improvement of religious character learning through the critical literacy of the Legend of the Kreo cave can be done through four activities, including the following. The first activity, before learning begins, the teacher begins learning by praying first. In the second activity, the teacher tells the story of Sunan Kalijaga. The third activity, the teacher instructs students to read the legendary text of the Kreo cave by using the seven stages that have been developed by Chamalah [4]. The fourth activity, teachers, and students evaluate the learning outcomes that have been implemented. With these four activities, it is hoped that it can improve the learning of religious character for students. This learning can actually be done in any learning/subject, either explicitly or implicitly. Although the main focus of this research is for literature learning.

\section{Conclusion}

Based on the description of the research results, it can be concluded as follows.

a) The symbolic meaning of the Kreo cave legend is (a) the legend of the Kreo cave as a symbol of obedience to God, (b) The Kreo cave legend as a symbol of the success of the Sunan Kalijaga command, and (c) The Kreo cave legend as a symbol of the success of the Sunan Kalijaga command.

b) The critical literacy of the Legend of Kreo cave which is carried out in 7 stages, namely the first stage, motivates students to read The Legend of the Kreo cave. The second stage, instructs students to read the Legend text of the Kreo cave. In the third stage, students understand the text of the Legend of Kreo cave through several questions. The fourth stage is to criticize. The critical activity was carried out by answering reorganization questions, inference questions, and evaluation questions related to The Legend of the Kreo cave. The fifth stage, namely rewriting. At this stage, the students rewrote the Legend of the Kreo cave that had been read in summary form. The sixth stage, namely creating. At this stage, students produce another form of the Legend of the Kreo cave, namely in the form of creative writing of short stories, poetry, novels, or drama texts. The seventh stage is publishing. At this stage, students publish their writings on social media Facebook, Instagram, WhatsApp, or other social media.

c) Improving the learning of religious characters through the critical literacy of the Legend of the Kreo cave can be done through the following four activities. The first activity, before learning begins, the teacher begins learning by praying first. In the second activity, the teacher tells the story of Sunan Kajiaga. In the third activity, the teacher instructs students to read the text of the Legend of the Kreo cave using the seven stages that have been developed by [4]. The fourth activity, teachers, and students evaluate the learning outcomes that have been implemented. 


\section{References}

[1] Ariyanthi, Ni Putu Prima, et al. Development of Child Story Book Prototypes with Local Culture through Analysis of Attitudes and Early Literacy in Learning the Themes of Living in Harmony 2013 Curriculum Class 2 Elementary Schools. Undiksa Postgraduate Research Journal. 6 (1). (2016).

[2] Asmani, Jamal Ma'mur. Guidebook for Internalization of Character Education in Schools. Yogyakarta: DIVA Press (2011).

[3] Balfas, Anwar. Developing Students' Literacy and Critical Thinking Skills through Context-Based Literature Learning. Journal of Linguistics. 15 (29) pp. 154-163. https://ojs.unud.ac.id/index.php/linguistika/article/view/304 (2008).

[4] Chamalah, Evi et al. Reading Folklore with Critical Literacy. Semarang: Unissula Press (2020).

[5] Danandjaja, James. Indonesian Folklore, The Science of Gossip, Fairy Tales, and Others. Jakarta: Grafiti (2007).

[6] Geske, Andrejs and Antra Ozola. Factors Influencing Reading Literacy at the Primary School Level. International Journal Problems of Education In The 21st Century. 6 (1), pp. 71-77. http://citeseerx.ist.psu.edu /viewdoc/download?doi=10.1.1.400.572\&rep=rep1\&type=pdf (2008).

[7] Harsiati, Titi. Characteristics of Reading Literacy Questions in the PISA Program. Jurnal Litera. 17 (1): 90-106. https://journal.uny.ac.id/index.php/litera/ article/view/19048 (2018).

[8] Ismayani, R. Mekar. Creativity in Learning Semantic Literary Texts Literacy. Scientific Journal of Indonesian Language and Literature Education Program. 2 (2), pp. 67-86. http://e-journal.stkipsiliwangi.ac.id/ index.php/semantik/article/view/326/247 (2013).

[9] Johnson, H., \& Freedman, L. Developing Critical Awareness at the Middle Level: Using Texts as Tools for Critique and Pleasure. Newark, DE: International Reading Association (2005).

[10] Ministry of Education and Culture. School Literacy Movement Master Design. Jakarta: Directorate General of Primary and Secondary Education (2016).

[11] The Ministry of National Education. Development of Cultural Education and National Character. Jakarta: Development of Cultural Education and National Character (2010).

[12] Kern, Richard. Literacy \& Language Teaching. Oxford : Oxford University Press (2000).

[13] Luxemburg, Jan Van et al. Introduction to Literature (Dick Hartoko Translation). Jakarta: Gramedia (1984).

[14] Muthoharoh, and Hasti Prastaningsih. Preserving the Literary Culture of Literature through Literacy through Digital Literacy in the Millennial Era. Rima Journal: Journal of Education, Indonesian Language and Literature Study Program. 9 (1), pp. 99-104. http://jurnal.umt.ac.id/index.php/lgrm/article/view/ 2404/0 (2020).

[15] Musfiroh, Tadkiroatun and Beniati Listiyorini. Literacy Competency Construct for Elementary School Students. Litera Journal. 15(1), pp. 1-15. Obtained from ttps://journal.uny.ac.id/index.php/ litera/article/view/9751 (2016).

[16] OECD. PISA 2012 Result in Focus. Program for International Student Assessment, 114.http://doi.org/10.1787.9789264208070-en (2014). 
[17] Oktariana, Ary. Character Education for Reading Loves through the Literacy Program at SDN Golo Yogyakarta. Journal of Primary School Teacher Education, Edisi 30 (2018).

[18] Omeri, Nopan. The Importance of Character Education in the World of Education. Journal of Education Managers. 9 (3), pp. 464-468 (2015).

[19] Prasetyo, Angga Teguh and Sahlan, Asmaun. Character Education Based Learning Design. Jogjakarta: Ar-Ruzz Media (2012).

[20] Rahardjo. Character Education as an Effort to Create Noble Morals. Journal of Education and Culture. 16(3) (2010).

[21] Rahman, Yuni and Cutri Atjalau. Critical Literacy Culture. Pedagogy: Journal of Education. 8 (2): $321-332 . \quad$ http://ojs.umsida.ac.id/index.php/pedagogia/ article/view/2430 (2019).

[22] Sudikan, Setya Yuwana. Oral Literature Research Methods. Surabaya:Citra Wacana Press (2001).

[23] Sugiyono. Mix Methods. Bandung: Alfabeta (2015).

[24] Sukmadinata, Nana Syaodih. Educational Research Methods. Bandung: PT Remaja Rosdakarya (2012).

[25] Sulistyorini, Dwi and Eggy Fajar Andalas. Oral Literature, Theory Study and Its Application in Research. Malang: Madani (2017)

[26] Sumaryanti, Lilis. Cultivating Literacy in Early Childhood Using Storytelling Methods. Jurnal AL-AASIYYA Journal Of Basif Education, 3 (1), pp. 117 (2018).

[27] Syahrani, Agus. Oral Culture VS Malay Student Literacy Culture: Implications for Student Learning Models. Journal of Social Sciences and Humanities. 4 (2), pp. 153176. http://wacanaetnik.fib.unand.ac.id/index.php /wacanaetnik/article/view/54 (2013).

[28] Syahrul, Ninawati. Youth Literature (Teen lit) as Alternative Media in Improving Literacy Culture. Parafrase Journal, 17 (2), pp. 9-19. http://jurnal.untagsby.ac.id/index.php/parafrase/article/view/1367 (2017).

[29] Tilaar, H.A.R. Critical Pedagogy. Jakarta : Rineka Cipta (2011).

[30] Constitution of the Republic of Indonesia Number 20 of 2003. National Education System, Jakarta (2003).

[31] Warsihna, Jaka. Improve Reading and Writing Literacy with Information and Communication Technology (ICT). Kwangsan Journal. 4 (2), pp. 67-80 (2016).

[32] Wulandari, Ayu et al. Pup-Up the Legend of Sindoro Sumbing based on local wisdom as a medium for student literacy. Transformatics: Journal of language, literature, and teaching 2 (2) (2018).

[33] Yahya Khan, D. Character Education Based on Self Potential, Boosting the Quality of Education. Yogyakarta: Pelangi Publishing (2010). 